The Treasures of Darkness 


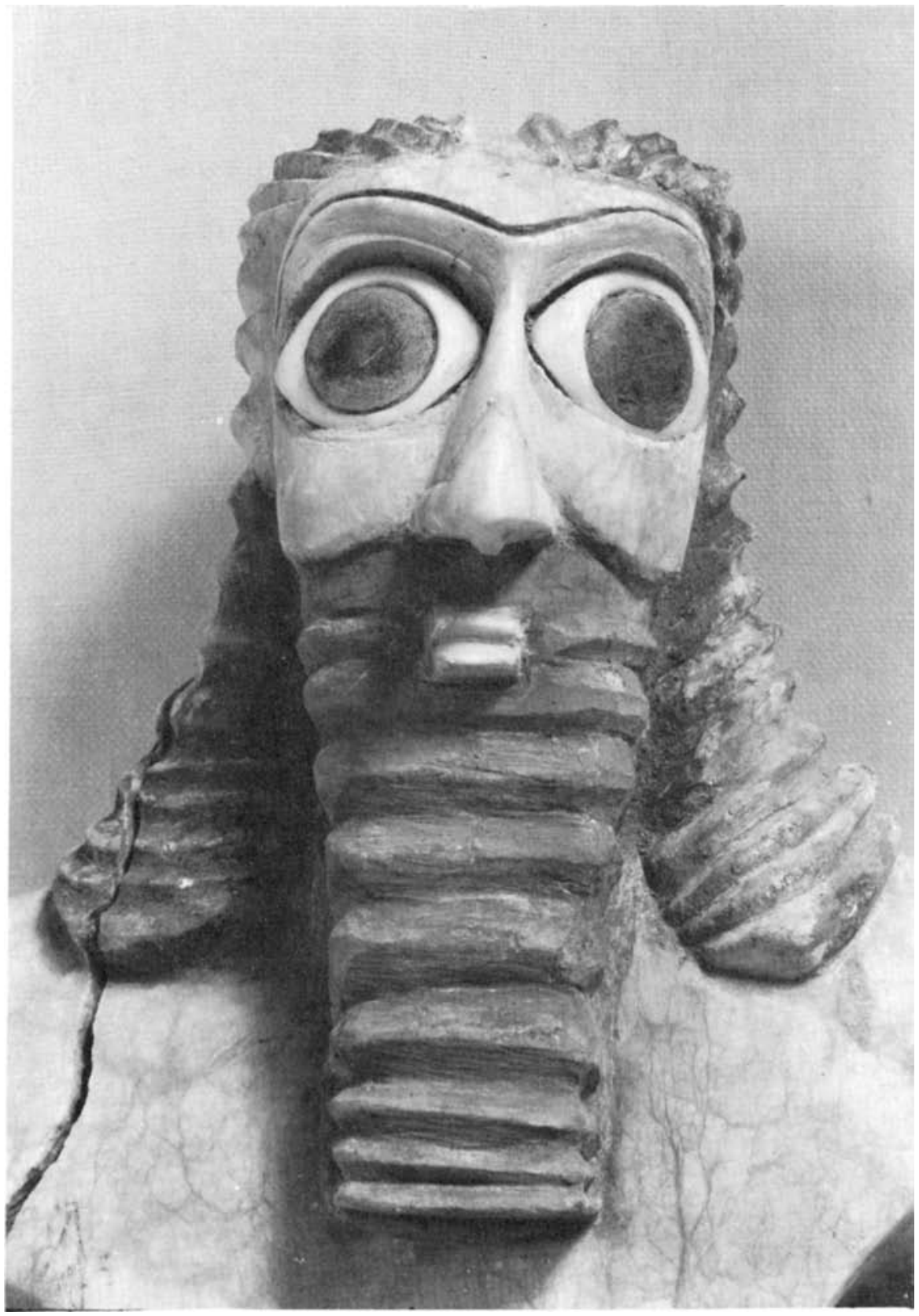

Head of a statue of Ninurta, god of the thundershowers and floods of spring. The statue was found in ancient Eshnunna (modern Tell Asmar) by the Iraq expedition of the Oriental Institute of the University of Chicago and dates from shortly after 3000 B.C. 


\title{
The Treasures of Darkness
}

\section{A HISTORY OF MESOPOTAMIAN RELIGION}

\author{
THORKILD JACOBSEN
}

YALE UNIVERSITY PRESS, NEW HAVEN AND LONDON 
Copyright $(\mathcal{O} 1976$ by Yale University.

All rights reserved. This book may not by reproduced, in whole or in part, in any form (beyond that copying permitted by Sections 107 and 108 of the U.S. Copyright law and except by reviewers for the public press), without written permission from the publishers.

Library of Congress catalog card number: 75-27576

International standard book number: 0-300-02291-3 (paper)

Designed by Sally Sullivan and set in Baskerville type. Printed in the United States of America.

Permission to quote has been given by the following:

The E. M. Forster Literary Estate and the Hogarth Press for a short extract from Anonymity: An Enquiry by E. M. Forster; The University of Chicago Press for translations from The Intellectual Adventure of Ancient Man by H. and H. A. Frankfort, John A Wilson, Thorkild Jacobsen, and William Irwin (copyright by the University of Chicago Press, 1946), and from The Burden of Egypt by John A. Wilson (copyright 1951 by the University of Chicago); The Oriental Institute, University of Chicago for translations from Most Ancient Verse by Thorkild Jacobsen and John A. Wilson (University of Chicago Press, 1963).

Thanks are due to the Trustees of the British Museum, the Directorate General of Antiquities, Baghdad, and the Oriental Institute, University of Chicago, for permission to publish photographs of objects in their collections. 
To Katryna 
